\title{
Analyses of the 1990 chest health survey of china clay workers
}

\author{
E M Rundle, E T Sugar, C J Ogle
}

\begin{abstract}
During 1990 all present and retired china clay workers in the United Kingdom were invited to take part in a chest health survey. A total of 4401 china clay workers participated representing over $70 \%$ of current employees and $17 \%$ of pensioners. The survey consisted of a chest $x$ ray film, lung function measurements, and a questionnaire on respiratory symptoms and smoking habits. The chest $x$ ray films were read by three readers to the International Labour Office (ILO) 1980 classification. Full details of occupational history for each participant were available and for each employee an estimate of total exposure to china clay dust was derived from representative dust concentrations for each location and job. These were based on measured dust concentrations after 1978 and on estimates before 1978. Analyses of the data were carried out to investigate the relations between exposure, $x$ ray film category, lung function, and respiratory symptoms. The percentage of people with small opacities greater than major $x$ ray film category 1 was $0 \cdot 8 \%$ (lower than in previous studies). Dust concentrations have been reduced in recent years, averaging $1.7 \mathrm{mg} \mathrm{m}^{-3}$ for dryers in 1990 compared with $3.5 \mathrm{mg} \mathrm{m}^{-3}$ in 1978. The lower effect of exposure after 1971, compared with earlier exposure, was confirmed by the analyses. After 1971 the milling of dried china clay (Atritor mills) was found to be the occupation with the highest effect on $x$ ray film category.

The relation between total exposure to china clay dust and $x$ ray film category is such that a typical non-smoker worker employed in the most dusty of current occupations may expect to reach the lower limit of category 1 after about 42 years continuous employment in that job at current exposures. Both forced
\end{abstract}

ECC International Ltd, John Keay House, St Austell, Cornwall PL.25 4DJ

E M Rundle, E T Sugar, C J Ogle vital capacity (FVC) and forced expiratory volume in one second $\left(F E V_{1}\right)$ were found (as in other studies) to decline with age, more rapidly for smokers than non-smokers at the rates for FVC of $0.0351 / y$ and $0.0331 / y$, whereas for $F E V_{1}$ the rates are $0.0391 / y$ for smokers and $0.034 \mathrm{l} / \mathrm{y}$ for non-smokers. Changes in $x$ ray film category are also related to lung function, a change of one major category being equivalent to about six years of ageing in its effect on $\mathrm{FEV}_{1}$.

(British fournal of Industrial Medicine 1993;50:913-919)

Previous surveys of china clay workers were carried out in 1961,1 1977, 1981 (unpublished), and $1985 .^{3}$ The aim of each survey has been to understand more fully the relations between dust exposure and chest health. Since 1981 the surveys have been available to all in the industry (as opposed to only those in dusty occupations). The 1990 survey was the first to have available full occupational history and epidemiological $x$ ray film readings for all participants, rather than for the largest employing company only, as in $1985 .^{3}$

The proportion of abnormal $x$ ray films is now lower than in earlier surveys. ${ }^{1-3}$ This has required great concentration on film quality to provide statistical conclusions at low levels of incidence and at low degrees of abnormality.

In earlier surveys the durations of employment in different jobs were used as possible explanatory variables for the changes in $x$ ray film readings. In this survey an estimate has been made of the cumulative respirable dust exposure for each employee to allow more direct relations to be investigated.

\section{Subjects and methods} SURVEY

The 1990 survey was offered to all china clay workers in the United Kingdom, and to most other employees of the largest china clay company regardless of their occupation. Of the 7456 people who participated, 4401 were in the china clay 
industry. The analyses presented here relate to these 4401 people (about $70 \%$ of the total china clay industry).

The $x$ ray film survey used British Coal's mobile chest $x$ ray film unit staffed by experienced radiographers. A $40 \times 40 \mathrm{~cm} x$ ray film was taken of each person, and for the first time this was developed on site, immediately, with a Rapitech processor. It was therefore possible to maintain film quality at a high and consistent level by working to previously agreed standards of optical density and image contrast and by making adjustments where necessary.

For each participant forced vital capacity (FVC) and forced expiratory volume in one second $\left(F_{E V}\right)$ were measured five times with a Vitalograph spirometer. Previously collected details of occupational history were validated during the survey and, where necessary, were updated. A questionnaire of respiratory symptoms and smoking habits was also completed, based on that of the MRC as used in the previous surveys.

\section{DUST CONCENTRATIONS}

Since 1978 dust concentrations have been regularly sampled, about 500 samples being taken each year with the emphasis on inspecting the dustier locations according to their numbers of workers. The samples were taken with either personal sampling pumps fitted with the Casella/MRC cyclone heads or MRDE 113A gravimetric samplers. Both respirable and total dust concentrations were calculated.

The average dust concentrations (together with their upper decile shown in parentheses) in 1978 were $4.7 \mathrm{mg} \mathrm{m}^{-3}(9.32)$ for Atritor mills, $3.5 \mathrm{mg}$ $\mathrm{m}^{-3}(5.41)$ for dryers, $3.5 \mathrm{mg} \mathrm{m}^{-3}$ (3.93) for calciners, and $1.6 \mathrm{mg} \mathrm{m}^{-3}$ (based on two samples) for slurry plants. Dust concentrations have been reduced and at the time of the survey the averages (and upper deciles) were $2.1 \mathrm{mg} \mathrm{m}^{-3}$ (3.36) for Atritor mills, $1.7 \mathrm{mg} \mathrm{m}^{-3}(2.78)$ for dryers, $2.2 \mathrm{mg}$ $\mathrm{m}^{-3}(3 \cdot 25)$ for calciners, and $1.2 \mathrm{mg} \mathrm{m}^{-3}(2 \cdot 26)$ for slurry plants.

\section{TOTAL OCCUPATIONAL DUST DOSE}

An estimate of the total occupational dust dose (TODD) for each participant has been made by combining the data on dust concentrations with occupational history details. The creation of the TODD has allowed dose response analyses to be carried out. Because there are few measurements taken at non-dusty locations and because regular sampling did not start until 1978, it was necessary to make estimates for a part of the data based on knowledge and experience. Also it was not possible to estimate dust concentrations for previous work outside the industry (the analyses implicitly assume that there was no exposure).
The TODD ( $\mathrm{mg} \mathrm{m}^{-3} \mathrm{y}$ ) for each employee was calculated by adding together the average respirable dust concentration $\left(\mathrm{mg} \mathrm{m}^{-3}\right)$ for each year based on his employment in that year. Some $60 \%$ of the china clay employees in the survey had TODD values of $10 \mathrm{mg} \mathrm{m}^{-3} \mathrm{y}$ or less, $88 \%$ had values of $30 \mathrm{mg} \mathrm{m}^{-3} \mathrm{y}$ or less, and $1 \cdot 1 \%$ had values greater than $80 \mathrm{mg} \mathrm{m}^{-3} \mathrm{y}$.

\section{RESPONSE TO SURVEY}

Although the survey was open to all current and retired workers in the china clay industry, the response, as in the previous surveys, was incomplete and averaged $71 \%$ for current employees. For those currently employed in potentially dusty occupations (dryers, Atritor mills, and calciners) and in slurry plants and tube presses, the responses ranged from $85 \%$ to $90 \%$ compared with $60 \%$ to $70 \%$ for those in occupations entailing little or no exposure (wet processing, staff).

The response from retired employees was low (17\%) despite great efforts to inform and to encourage those eligible. It was decided to include these data in the analyses despite the low numbers because of the higher incidence of lengthy and high exposure. In calculating the total exposure for pensioners a higher proportion of estimates was necessary than for current employees because of exposure before 1978. The TODD experienced by the pensioners was somewhat higher than for the overall respondents; only $41 \%$ having a TODD of less than $10 \mathrm{mg} \mathrm{m}^{-3} \mathrm{y}$, (compared with $60 \%$ overall), and $4 \%$ having a TODD of greater than $80 \mathrm{mg} \mathrm{m}^{-3} \mathrm{y}$ (compared with $1 \cdot 1 \%$ overall).

For those still in employment, response for most age groups was reasonably consistent, with a slightly lower response for those younger than 30 .

\section{RAY FILM READINGS}

The films for all 7456 survey participants were randomised and divided into batches of 57 for reading. To ensure consistent reading standards, three trigger films with previously agreed readings were randomly inserted into each batch and the agreed result was reported to the reader after each trigger. No information other than the $x$ ray film number was made available to the reader, all identification being blanked out so that readings were unbiased. Each batch of films was read by three experienced readers from a panel of five, reading to the International Labour Office (ILO) 1980 classification. ${ }^{4}$ The choice of the three readers was based on availability and with the intention that no reader should read more than two thirds of all films. There was no systematic allocation of films to triplets of readers and therefore any bias caused by differences in readings would affect only the precision of the regression or analyses. 


\section{LUNG FUNCTION}

Two Vitalograph spirometers were used during the survey to measure FVC and $\mathrm{FEV}_{1}$. These were calibrated three times a day taking account of ambient room temperature. Each participant made five blows (unless unable to complete the test). The average of the best three results was calculated for each participant (FVC and $\mathrm{FEV}_{1}$ independently) for use in subsequent analyses. ${ }^{5}$ Each person's height, sex, and age were also recorded.

\section{EXCLUSIONS}

From the 4401 respondents who are employed in the china clay industry or are retired from it, a number were excluded from epidemiological analyses: 269 women (all with no dust exposure), 12 pensioners aged 80 or over, three persons whose $x$ ray films were recorded as unreadable by one or more readers, and five persons whose $x$ ray films were not read epidemiologically.

This provided a data set for analysis of $x$ ray film readings of 4112 persons. In the analyses of lung function and respiratory symptoms this was further reduced to 4096 (because of missing information on 16 people).

\section{JOB GROUPINGS}

Individual jobs recorded on occupational histories were combined into groups for analysis according to the amount of dust exposure, but keeping separate the important types of processing plants. As in the 1985 survey, ${ }^{3}$ times spent after and before 1971 were kept separate because of the differences in working conditions and the more precise results that the analyses produced. Time spent before employment began, after retirement, and in jobs with little or no dust (less than $0.5 \mathrm{mg} \mathrm{m}^{-3}$ ) were added together to form a "non-dusty life" for each employee. The job groupings used for analyses were: dryers before 1971 and after 1971, calciners before 1971 and after 1971, slurry plants and tube presses, press and pan kilns, china stone mills, Atritor mills before 1971 and after 1971, non-dusty life, and external employment.

\section{STATISTICAL METHODS}

The computer package GLIM (Generalised Linear Interactive Modelling) by the Numerical Algorithms Group, was used to perform statistical analyses of the data. ${ }^{6}$

For the analysis of relations between $x$ ray film score, occupational history, TODD, and lung function multiple linear regression models were fitted. The relations between the incidence of respiratory symptoms and other variables were investigated with logistic regression, an appropriate technique for modelling probabilities of binary outcomes. Tests of significance were carried out with the stu- dent $t$ test and the $\chi^{2}$ test. Correlation was measured by the multiple and partial correlation coefficient ( $R$ and $\mathbf{r}$ ).

\section{CONVERSION OF X RAY FILM CATEGORY TO NUMERICAL SCORE}

The method adopted in the 1985 survey $^{3}$ and based on the method of Oldham ${ }^{7}$ was used to find a numerical score for each film.

On the assumption that readings are drawn from a continuum and are normally distributed, the major categories for each reader were plotted on a probability scale to transform the cumulative frequency distribution into a straight line from which the positions of the subcategories were found by interpolation. The lines for each reader (fitted with the method of maximum likelihood) were found to be effectively parallel and close together, and therefore a central line was used to derive scores for all readers.

The scores for each subcategory resulting from this procedure were: $0 /-=-2 \cdot 718,0 / 0=-1 \cdot 014$, $0 / 1=0.754,1 / 0=1 \cdot 162,1 / 1=1 \cdot 583,1 / 2=1 \cdot 920$, $2 / 1=2 \cdot 061,2 / 2=2 \cdot 351,2 / 3=2 \cdot 713,3 / 2=2 \cdot 865$, $3 / 3=3 \cdot 044$.

On the basis that a reader would need to be more sure of a reading to place it into a narrow subcategory, a weight inversely proportional to its width was attached to each subcategory, in averaging the three readings. Finally the transformation $y=\left(85+11 x^{2}-36 x^{-2}\right) / 60$ was applied to the average score to convert the lowest point of the axis from $-\infty$ to 0 .

\section{Results \\ CHEST RADIOGRAPHS: EPIDEMIOLOGICAL READINGS Film quality}

The efforts to maintain high film quality resulted in $99 \%$ of films being interpreted as quality 2 or better and $70 \%$ of films as quality 1 (Readers admitted to applying more exacting standards in downgrading on film quality than in other surveys). Only three films were recorded as quality 4 (unreadable) by any reader, and these were excluded from the analysis.

\section{LARGE OPACITIES}

Of the $4112 x$ ray films for the china clay workers, two were classified as showing large opacities of size A (by each of the three readers). One film was that of an employee who had been employed only in low dust areas, but had previously been a farmer for 25 years. For this film the small opacities were recorded as category 1 . The other film was that of an employee who had been employed in an old china clay drying plant (18 years). For this film the small opacities were recorded as category 2 . 
PLEURAL CHANGES

Of the 4112 china clay workers nine were found to have pleural calcification by two or more readers ( 23 by one or more reader). There were 39 cases of pleural thickening recorded by two or more readers ( 82 by one or more).

\section{SMALL OPACITIES}

Profusion

Table 1 shows the distribution of $x$ ray film categories (the median of the readings) for the total set of 4112 persons and for each smoking class. Table 2 shows the distribution of the median reading of the $x$ ray film category by age.

The conformity amongst readers was high. The readers' scores varied by three or more subcategories for only 120 films $(2.9 \%)$, and by four or more subcategories for 14 films. Of these 14 films, 11 were recorded by two or more readers as having other disease present.

Comparison between pairs of readers showed that for films above category $0 / 1$ there was on average less than one subcategory difference between the two extreme readers. The average score for $x$ ray films read by the highest three readers would have averaged much less than one subcategory higher than if the same films had been read by the three lowest readers.

\section{SHAPE AND SIZE}

Analysis of the median reading from an assumed continuum, from pure rounded to pure irregular, was carried out. This showed that $50 \%$ of opacities were either pure or predominantly rounded (normally associated with dust exposure). In the previous survey $60 \%$ were found to be pure or predominantly rounded, and in particular the proportion of pure rounded opacities in the 1990 survey was only $4 \%$ compared with $28 \%$ in $1985 .^{3}$

The proportion of irregular opacities for smokers and ex-smokers was not significantly higher than for non-smokers. This again contrasts with the findings of the 1985 survey. ${ }^{3}$ An examination of the individual readings of the shape of small opacities showed large variations among the readers. In $50 \%$ of films read as $0 / 1$ or higher the readers differed as to whether the shapes of the opacities were rounded or irregular. The agreement between readers was

Table 1 Distribution of the median $x$ ray film readings of small opacities by smoking class

\begin{tabular}{|c|c|c|c|c|c|}
\hline \multirow{2}{*}{$\begin{array}{l}\text { Smoking } \\
\text { class }\end{array}$} & \multirow[b]{2}{*}{ Total } & \multicolumn{4}{|c|}{ Major $x$ ray film category } \\
\hline & & 0 & 1 & 2 & 3 \\
\hline $\begin{array}{l}\text { Non-smokers } \\
\text { Ex-smokers } \\
\text { Current smokers }\end{array}$ & $\begin{array}{l}1466 \\
1210 \\
1436\end{array}$ & $\begin{array}{l}1396 \\
1045 \\
1258\end{array}$ & $\begin{array}{r}60 \\
150 \\
168\end{array}$ & $\begin{array}{r}10 \\
14 \\
9\end{array}$ & $\begin{array}{l}0 \\
1 \\
1\end{array}$ \\
\hline Total & 4112 & 3699 & 378 & 33 & 2 \\
\hline
\end{tabular}

Table 2 Distribution of $x$ ray film category by age

\begin{tabular}{lrllll}
\hline \multicolumn{7}{c}{ Major x ray film category } \\
\cline { 3 - 6 } Age & Total & \multicolumn{1}{l}{0} & 1 & 2 & 3 \\
\hline$<20$ & 118 & 118 & - & - & - \\
$21-30$ & 713 & 701 & 12 & - & - \\
$31-40$ & 917 & 894 & 23 & - & - \\
$41-50$ & 1101 & 998 & 99 & 4 & - \\
$51-60$ & 822 & 669 & 138 & 14 & 1 \\
$61-70$ & 362 & 260 & 89 & 12 & 1 \\
$71-80$ & 79 & 59 & 17 & 3 & - \\
& & & $378(9 \cdot 19)$ & $33(0 \cdot 80)$ & $2(0 \cdot 05)$ \\
\hline
\end{tabular}

better at higher profusions. In the 35 films with a median reading of $2 / 1$ or higher, in no case was a film read as pure rounded by one reader and pure irregular by another.

Two readers have commented on the difficulty of being specific as to the type and cause of abnormalities at the low levels found in the survey. This emphasises the need to maintain the highest possible film quality in surveys of this kind.

\section{REGRESSION ANALYSES OF SMALL OPACITIES \\ Occupational histories}

The method of Oldham ${ }^{2}$ was used to examine the relation between $x$ ray film category and occupational history. The natural logarithm of the numerical score was regressed on the duration of employment in the various job groupings (and nondusty life).

In preliminary analyses the smoking class of each subject was used as an additional factor, but was found to have no statistical significance. External employment was found to be not significantly different from non-dusty life and these were combined in subsequent analyses.

As in the analyses of the 1985 survey, ${ }^{3}$ a distinction was drawn between early (before 1971) and late (after 1971) exposure. The older drying processes (pan kilns), and the milling of china stone were phased out around this time. The models incorporating this distinction gave improved statistical relations.

Table 3 shows the regression coefficients of 1000 $x \log _{e}$ ( $x$ ray film score) on years of exposure in the various job categories, together with the number of people with greater than one month of employment in that category. The table also shows the average and maximum durations of employment for those employed in each job. The variance accounted for in this analysis was $21 \cdot 7 \%,(R=0.47)$. The table also gives the $\mathrm{SD}$ around the regression line.

\section{TOTAL OCCUPATIONAL DUST DOSE}

A direct relation was sought between the dust exposure for each subject and the $x$ ray film category. This was done by regressing the natural logarithm 
Table 3 Regression coefficients of $1000 \times \log _{e}(x$ ray film score) on years of exposure in job categories

\begin{tabular}{|c|c|c|c|c|c|}
\hline fob classification & No of subjects & $\begin{array}{l}\text { Maximum } \\
\text { employment (y) }\end{array}$ & $\begin{array}{l}\text { Average } \\
\text { employment (y) }\end{array}$ & $\begin{array}{l}\text { Regression } \\
\text { coefficients }\end{array}$ & $S E$ \\
\hline $\begin{array}{l}\text { Non-Dusty Life } \\
\text { Dryers: }\end{array}$ & 4112 & $78 \cdot 0$ & $37 \cdot 7$ & $7 \cdot 7$ & 0.4 \\
\hline $\begin{array}{l}\text { Before } 1971 \\
\text { After } 1971 \\
\text { Slurry and tube presses }\end{array}$ & $\begin{array}{r}456 \\
1218 \\
493\end{array}$ & $\begin{array}{l}27 \cdot 4 \\
19 \cdot 5 \\
47 \cdot 0\end{array}$ & $\begin{array}{l}5 \cdot 7 \\
8 \cdot 5 \\
9 \cdot 6\end{array}$ & $\begin{array}{r}29 \cdot 2 \\
13 \cdot 0 \\
8 \cdot 9\end{array}$ & $\begin{array}{l}2 \cdot 2 \\
1 \cdot 1 \\
1 \cdot 2\end{array}$ \\
\hline Calciners: & & & & & \\
\hline $\begin{array}{l}\text { Before } 1971 \\
\text { After } 1971 \\
\text { Pan kilns } \\
\text { China stone mills } \\
\text { Atritor mills: }\end{array}$ & $\begin{array}{r}68 \\
274 \\
202 \\
37\end{array}$ & $\begin{array}{l}22 \cdot 8 \\
19 \cdot 5 \\
36 \cdot 9 \\
18 \cdot 4\end{array}$ & $\begin{array}{l}5 \cdot 4 \\
7 \cdot 6 \\
6 \cdot 4 \\
5 \cdot 8\end{array}$ & $\begin{array}{r}12 \cdot 2 \\
9 \cdot 4 \\
22 \cdot 7 \\
30 \cdot 6\end{array}$ & $\begin{array}{l}5 \cdot 3 \\
2 \cdot 1 \\
2 \cdot 6 \\
5 \cdot 3\end{array}$ \\
\hline $\begin{array}{l}\text { Before } 1971 \\
\text { After } 1971\end{array}$ & $\begin{array}{r}82 \\
151\end{array}$ & $\begin{array}{l}17 \cdot 8 \\
19 \cdot 5\end{array}$ & $\begin{array}{l}4 \cdot 6 \\
6 \cdot 8\end{array}$ & $\begin{array}{l}46 \cdot 9 \\
21 \cdot 1\end{array}$ & $\begin{array}{l}6 \cdot 1 \\
3 \cdot 3\end{array}$ \\
\hline
\end{tabular}

Constant $-823 \cdot 7$; residual deviation $0 \cdot 313$.

of $x$ ray film score on TODD and age. It was found that improved statistical fits were obtained by incorporating the different smoking classes, which had not been the case in the occupational history analyses.

Table 4 shows the regression coefficients of $x$ ray film score on TODD, age, and smoking class. The variance accounted for in this analysis was $22.2 \%$ $(R=0.47)$. Table 4 also shows the equivalent regression coefficients for a model in which there is no ageing effect on $x$ ray film score for non-smokers, as is commonly assumed. This model was not as good; the variance accounted for was $19.0 \%(R$ $=0.43$ ).

\section{LUNG FUNCTION}

Regression analyses

The lung function measurements were normalised to a height of $1.7 \mathrm{~m}$ as recommended by Cole. ${ }^{8}$ The average of the best three results for FVC and FEV were regressed on $x$ ray film score, age, and occupational history (or TODD), with smoking class as an additional factor. Although lung function is most heavily dependent on age and smoking class,

Table 4 Regression coefficients of $1000 \times \log _{e}(x$ ray score $)$ on total occupational dust dose, age, and smoking classification

\begin{tabular}{|c|c|c|c|c|}
\hline & \multirow[b]{2}{*}{$\begin{array}{l}\text { Regression } \\
\text { coefficients }\end{array}$} & \multirow[b]{2}{*}{$S E$} & \multicolumn{2}{|l|}{$\begin{array}{l}\text { Age for non- } \\
\text { smokers } \\
\text { constrained } \\
\text { to be } 0\end{array}$} \\
\hline & & & $\begin{array}{l}\text { Regression } \\
\text { coefficients }\end{array}$ & $S E$ \\
\hline $\begin{array}{l}\text { Total occupational dust } \\
\left.\text { dose (mg m }{ }^{-3} \mathrm{y}\right) \\
\text { Age for non-smokers (y) } \\
\text { Age for ex-smokers (y) } \\
\text { Age for current smokers (y) } \\
\text { Constant }\end{array}$ & $\begin{array}{r}5 \cdot 7 \\
6 \cdot 1 \\
7 \cdot 3 \\
8 \cdot 0 \\
-834 \cdot 4\end{array}$ & $\begin{array}{r}0.3 \\
0.5 \\
0.4 \\
0.5 \\
17.5\end{array}$ & $\begin{array}{r}6 \cdot 9 \\
3 \cdot 1 \\
3 \cdot 2 \\
-634 \cdot 7\end{array}$ & $\begin{array}{r}0.3 \\
0.2 \\
0.3 \\
83.1\end{array}$ \\
\hline Residual deviation & 0.312 & & 0.318 & \\
\hline
\end{tabular}

the results showed that including $x$ ray film score gave more precision ( $r=0.11$, df 4107). Further inclusion of occupational history or TODD did not improve the goodness of fit.

Table 5 shows the regression coefficients of $\mathrm{FEV}_{1}$ and FVC on $x$ ray film score, age, and smoking class. The variance accounted for in these analyses were $48.5 \%(R=0.70)$ and $42.3 \%(R=$ $0.65)$ respectively. A change in $x$ ray film score of one major category has a similar effect on $\mathrm{FEV}_{1}$ as ageing of $6 \cdot 2$ years for non-smokers or $5 \cdot 4$ years for smokers.

\section{RESPIRATORY SYMPTOMS}

Table 6 shows, for each smoking class, the responses to respiratory symptom questions where the overall positive responses were greater than $5 \%$. The relation between the incidence of the respiratory symptoms and other variables were investigated by logistic regression. After standardising for age there were found to be significant differences between smoking class in the incidence of these symptoms other than for "cough and phlegm".

In each case $\mathrm{FEV}_{1}$ had by far the most significant relations with each of the symptoms. Unlike in the 1985 survey $^{3}$ improved correlations were obtained

Table 5 Regression coefficients of $F E V_{1}$ and $F V C$ in $m l$ (adjusted for height) on $x$ ray score, age, and smoking class

\begin{tabular}{lrrrrr}
\hline & \multicolumn{1}{l}{$F E V_{1}$} & & \multicolumn{2}{l}{$F V C$} \\
\cline { 2 - 3 } \cline { 5 - 6 } & $\begin{array}{l}\text { Regression } \\
\text { coefficients }\end{array}$ & \multicolumn{1}{c}{$S E$} & & $\begin{array}{l}\text { Regression } \\
\text { coefficients }\end{array}$ & $S E$ \\
\hline$x$ Ray film score & -210.80 & 29.40 & -356.40 & 32.75 \\
Age for non-smokers & -33.76 & 0.80 & -33.02 & 0.90 \\
Age for ex-smokers & -35.76 & 0.68 & -34.18 & 0.76 \\
Age for current smokers & -38.65 & 0.77 & -35.45 & 0.86 \\
Constant & 5206.00 & 31.27 & 6177.00 & 34.83 \\
Residual deviation & 0.53 & & & 0.59 & \\
\hline
\end{tabular}


Table 6 Percentage of positive responses to respiratory symptom questionnaire by smoking classification

\begin{tabular}{|c|c|c|c|c|}
\hline Symptom & Non-smokers & Ex-smokers & Current smokers & All \\
\hline $\begin{array}{l}\text { No of people } \\
\text { Usually cough during winter } \\
\text { Usually bring up phlegm during winter } \\
\text { One occurrence of cough and phlegm lasting for three weeks } \\
\text { or more during the past three years }\end{array}$ & $\begin{array}{r}1462 \\
8 \cdot 1 \\
11 \cdot 5 \\
6 \cdot 8\end{array}$ & $\begin{array}{r}1207 \\
10 \cdot 3 \\
14 \cdot 8 \\
9 \cdot 3\end{array}$ & $\begin{array}{r}1427 \\
17 \cdot 7 \\
20 \cdot 8 \\
8 \cdot 7\end{array}$ & $\begin{array}{r}4096 \\
12 \cdot 1 \\
15 \cdot 7 \\
8 \cdot 2\end{array}$ \\
\hline $\begin{array}{l}\text { Troubled by shortness of breath hurrying on level ground or } \\
\text { walking up a slight hill }\end{array}$ & 6.9 & $15 \cdot 7$ & $13 \cdot 7$ & $11 \cdot 9$ \\
\hline Sometimes chest sounds of wheezing or whistling & $12 \cdot 0$ & $18 \cdot 0$ & $31 \cdot 5$ & $20 \cdot 6$ \\
\hline
\end{tabular}

by also including smoking class as a separate factor. (Note that $\mathrm{FEV}_{1}$ is itself dependent on smoking classification). Additional smaller improvements were made by the introduction of either $x$ ray film score, age, or TODD.

\section{Discussion}

The analyses show that time spent working in china stone mills, pan kilns, Atritor mills and dryers has the highest effect on $x$ ray film category. Of these, only Atritor mills and dryers are still in use and the analysis shows exposure after 1971 to have a far lower effect than before 1971, the rates being less than half of the rates for the earlier period.

Of the current job groupings, employment in Atritor mills has the highest effect, then dryers, then calciners. This is consistent with the respirable dust concentrations in these locations.

Figure 1 shows the predicted relation of $x$ ray film category with age for current jobs. Non-dusty life, slurry plants, tube presses and calciners are shown as one line because they are so similar. For comparative purposes, figure 1 also shows the relations for dryers and mills in conditions before 1971 .

The use of dust exposure (TODD) as an independent variable in the analyses, rather than time spent in each job, has enabled the changing conditions within each job to be reflected. In the analyses

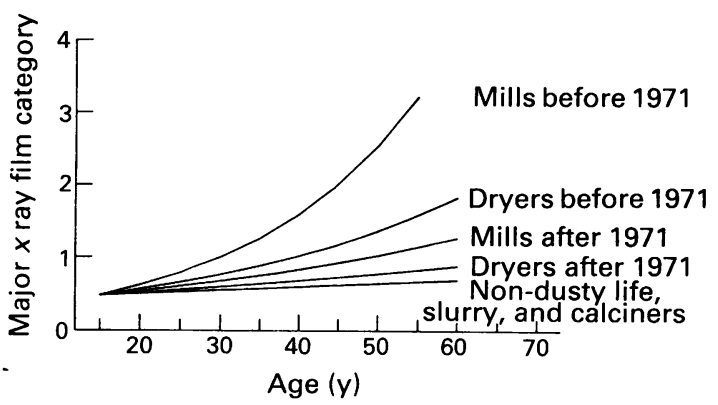

Figure 1 Predicted $x$ ray film category for continuous employment in the various job groupings. based on occupational history this can only be done by separating out jobs at different times, for example, before and after 1971. It is reassuring that the statistical fit for the dust exposure models are already as good as for those based on occupational history; a number of assumptions were necessary in assigning exposure to early employment before regular measurements began, and these will gradually become less important as time goes on and the proportion of measured dust data increases.

The findings with TODD are interpreted graphically for an average man aged 60 . Figure 2 shows the relations between TODD and $x$ ray film category for a non-smoker, an ex-smoker, and a current smoker. Expected values, and $95 \%$ confidence intervals (based on the SDs of the variables) are shown. A non-smoker will have on average reached the lower limit of major $x$ ray film category 1 at the age of 60 after a total exposure of $85 \mathrm{mg} \mathrm{m}^{-3} \mathrm{y}$, for example, by working continuously for 42.5 years at an average dust concentration of $2 \mathrm{mg} \mathrm{m}^{-3}$, (equating to about the current level of exposure in the most dusty operating conditions, Atritor mills). For a smoker the total exposure would need to be less, at $65 \mathrm{mg} \mathrm{m}^{-3} \mathrm{y}$.

In this survey as in others, a number of nonexposed employees had apparently developed small opacities compatible with pneumoconiosis. Of the 413 whose median $x$ ray film category was 1 or

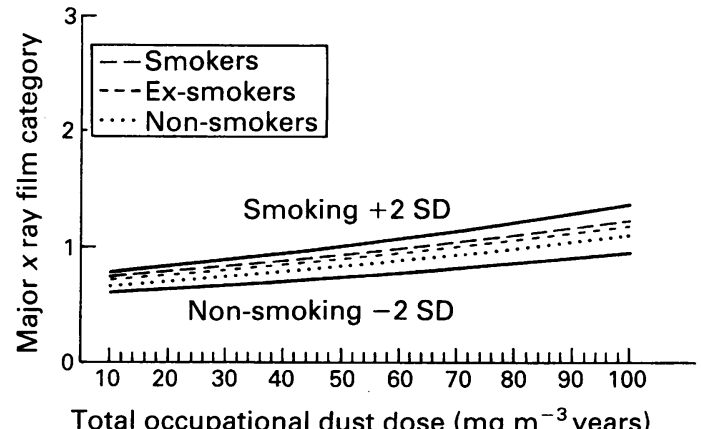

Figure 2 Estimates of $x$ ray film category for different smoking classes at age 60 . 
greater, 136 had no dust exposure (based on their job history). This represents $6 \cdot 1 \%$ of non-exposed employees. A similar level of background noise, not caused by exposure to china clay, was found in the 1985 survey $^{3}(5 \cdot 5 \%)$. Analysis of the 136 cases showed that although there were 116 smokers or ex-smokers (a higher proportion than in the overall population) there were nevertheless 21 non-smokers with no exposure who had developed small opacities. This finding is contrary to current assumptions; no attempt is made to explain it.

The $\mathrm{FEV}_{1}$ declines with age (more rapidly for smokers). $\mathrm{FEV}_{1}$ is also related to the $x$ ray film category with a difference of one major category equating to $6 \cdot 2$ years of ageing for a non-smoker. Similar results are found for FVC.

The incidences of respiratory symptoms are related to lung function results $\left(\mathrm{FEV}_{1}\right)$ for each smoking class. Dust exposure and $x$ ray film score have small additional effects.

We gratefully acknowledge the help from Professor CE Rossiter in the interpretation of the analyses, and advice on the statistical methods used, and $\mathrm{Dr}$ A Cockcroft for continuing advice on methodology.
We also thank the late Dr JC Gilson for his views and guidance to improve film quality, Drs $\mathrm{H}$ Thomas, I Coutts, JH Sewart, G Sheers, and A Cockcroft for reading the chest radiographs, and to Dr MJ Pemberton for reviewing the draft manuscripts.

1 Sheers G. Prevalence of pneumoconiosis in Cornish kaolin workers. Brf Ind Med 1964;21:218-25.

2 Oldham PD. Pneumoconiosis in Cornish china clay workers. Br f Ind Med 1983;40:131-7.

3 Ogle CJ, Rundle EM, Sugar ET. China clay workers in the south west of England: analysis of chest radiograph readings, ventilatory capacity, and respiratory symptoms in relation to type and duration of occupation. Br $\mathrm{F}$ Ind Med $1989 ; 46: 261-70$

4 International Labour Office. ILO 1980 International Classification of Radiographs of Pneumoconiosis. Geneva: ILO, 1980. (Occupational safety and health series No $22(\mathrm{rev})$.)

5 Oldham PD, Cole TJ. Estimation of the FEV $1 \cdot 0$. Thorax 1983;38:662-7.

6 Numerical Algorithms Group. The GLIM system, release 3.77 manual. Oxford: Numerical Algorithms Group 1976. (Rev A.)

7 Oldham PD. Numerical scoring of radiological pneumoconiosis. In: Walton WH, ed. Inhaled particles III. London: Unwin, 1971:621-30.

8 Cole TJ. Linear and proportional regression models in the prediction of ventilatory function. Fournal of the Royal Statistical Society series A 1975;138:297-338.

Accepted 11 January 1993

\section{Vancouver style}

All manuscripts submitted to the $B r \mathcal{F}$ Ind Med should conform to the uniform requirements for manuscripts submitted to biomedical journals (known as the Vancouver style.)

The $\mathrm{Br} \mathcal{F}$ Ind $\mathrm{Med}$, together with many other international biomedical journals, has agreed to accept articles prepared in accordance with the Vancouver style. The style (described in full in $\mathrm{Br}$ f Ind Med, 24 February 1979, p 532) is intended to standardise requirements for authors.

References should be numbered consecutively in the order in which they are first mentioned in the test by Arabic numerals above the line on each occasion the reference is cited (Manson ${ }^{1}$ confirmed other reports $\mathrm{s}^{2-5} \ldots$. . In future references to papers submitted to the $B r \mathcal{F}$ Ind Med should include: the names of all authors if there are six or less or, if there are more, the first three followed by et al; the title of journal articles or book chapters; the titles of journals abbreviated according to the style of Index Medicus; and the first and final page numbers of the article or chapter.

Examples of common forms of references are:

1 International Steering Committee of Medical Editors, Uniform requirements for manuscripts submitted to biomedical journals. $\mathrm{Br}$ F Ind Med 1979;1:532-5.

2 Soter NA, Wasserman SI, Austen KF. Cold urticaria: release into the circulation of histamine and eosinophil chemotactic factor of anaphylaxis during cold challenge. N Engl F Med 1976;294:687-90.

3 Weinstein L, Swartz MN. Pathogenic properties of invading micro-organisms. In: Sodeman WA Jr, Sodeman WA, eds. Pathologic physiology, mechanisms of disease. Philadelphia: W B Saunders, 1974:457-72. 